\title{
Treatment outcomes of 213 breast cancer patients after sentinel lymph node biopsy - single center experience
}

Piotr Kędzierawski ${ }^{1}$, Artur Bocian², Izabela Ciepiela ${ }^{1}$, Agnieszka Kołacińska ${ }^{3,4}$, Paweł Macek ${ }^{5}$, Stanisław Góźdź

\begin{abstract}
${ }^{1}$ Radiotherapy Department, Holycross Cancer Centre, Kielce, Poland ${ }^{2}$ Surgical Oncology Clinic, Holycross Cancer Centre, Kielce, Poland ${ }^{3}$ Department of Head and Neck Cancer Surgery, Medical University of Lodz, Lodz, Poland

${ }^{4}$ Department of Surgical Oncology, Medical University of Lodz, Lodz, Poland ${ }^{5}$ Epidemiology and Cancer Care Department, Holycross Cancer Centre, Kielce, Poland ${ }^{6}$ Clinical Oncology Clinic, Holycross Cancer Centre, Kielce, Poland
\end{abstract}

Submitted: 3 July 2017

Accepted: 18 September 2017

Arch Med Sci Civil Dis 2017; 2: e130-e134

DOI: https://doi.org/10.5114/amscd.2017.70893

Copyright (c) 2017 Termedia \& Banach

\begin{abstract}
Introduction: The article presents the results of the management of patients with breast cancer treated in the Holycross Cancer Centre during the period 2008-2012. In all the patients, invasive breast cancer clinically node negative was diagnosed and multidisciplinary treatment with sentinel node biopsy was applied.
\end{abstract}

Material and methods: The study included a group of 213 women who had previously undergone surgery, breast-conserving and/or mastectomy. In 206 patients, the sentinel lymph node was identified. Due to metastasis to the sentinel lymph node in 32 patients axillary lymphadenectomy was performed and additionally in 7 patients due to the failure of sentinel lymph node identification. Due to the higher tumor burden 10 patients were subjected to more extensive surgical treatment - mastectomy. After surgical treatment the patients were qualified for adjuvant therapy. The mean time of observation of patients after treatment was 61 months.

Results: Relapse of the disease was noted in 7 patients, 5 patients died (4 patients due to the spread of the disease, 1 due to the second carcinoma - gastric cancer). Recurrence in the axillary region was observed in 1 patient, metastases to the lungs - in 1 patient, metastases to the liver - in 1, metastases to the ovary - in 1, and in 3 patients metastases to the bones. Based on analysis of the Kaplan-Meier estimator of the survival function, it was found that the probability of survival for 5 years without symptoms of the disease was $96.2 \%$, whereas the probability of overall 5 -year survival was $96.4 \%$.

Conclusions: The outcome of patients after sentinel lymph node biopsy was excellent. In breast cancer patients sentinel lymph node biopsy is safe and effective.

Key words: breast cancer, outcome, sentinel lymph node biopsy.

\section{Introduction}

Within recent years a paradigm shift in the extent of axillary surgery in breast cancer patients has been observed, i.e. radical excision of three levels of axillary lymph nodes and parasternal nodes (Urban mastectomy, 1952), axillary lymph node dissection (Patey, Madden mastectomy), sentinel lymph node biopsy (Giuliano AE, 1991, 1994), omission of axil-

\author{
Corresponding author: \\ Piotr Kędzierawski \\ Radiotherapy Department \\ Holycross Cancer Centre \\ 3 Artwińskiego St \\ 25-734 Kielce, Poland \\ Phone: +48 609211933 \\ E-mail: piotrkedzierawski@ \\ wp.pl
}


lary dissection in the case of macro- or micrometastases (ACOSOG American College of Surgeons Oncology Group Z0011 trial, year 2011, IBCSG 3201 International Breast Cancer Study Group year 2013), and abandonment of nodal procedures in early breast cancer (SOUND study - Sentinel node vs. Observation after axillary UltrasouND, Gentilini, Veronesi U 2012-2017, INSEMA-Intergroup-Sentinel-Mamma). The introduction of sentinel node biopsy into surgical treatment replaced routine axillary dissection. At present, this procedure is commonly used in patients with early-stage breast cancer with clinically unchanged lymph nodes. Randomized studies showed that in case of the absence of metastases to the axillary lymph node, axillary dissection is not necessary, avoiding complications [1-12]. Despite progressive decline in the extent of lymph node surgery in recent years, survival rates in breast cancer patients have improved and locoregional recurrence remains very low. In the Holycross Cancer Center (HCC) the sentinel lymph node biopsy has been performed since 2007. The current study presents HCC experience and outcome of breast cancer patients who had undergone multidisciplinary treatment with the use of sentinel lymph node biopsy.

\section{Material and methods}

The analysis included 213 patients with invasive breast cancer of no special type, stage I and II who received multidisciplinary treatment with the use of sentinel lymph node biopsy in the Holycross Cancer Center, during the period 2008-2012. Mean age of patients was $60.5 \pm 9.8$ years (minimum $=32.9$, maximum $=85.8$, median $=61.3$ years). The most frequently observed tumor diameter ranged between 10 and $20 \mathrm{~mm}$. The most often diagnosed histologic type was invasive ductal carcinoma of no special type $(87.3 \%$; $n=$ 186). All patients had grade 1 or 2 breast cancer. Table I presents the characteristics of patients. Lumpectomy with sentinel lymph node biopsy (SLNB) was performed in 202 patients, simple mastectomy with SLNB in 11 women. Due to more extensive disease 10 patients were subjected to the radicalization of surgical treatment - mastectomy. The number of sentinel lymph nodes identified and harvested ranged from 0 to 10, with a median of 2. After histopathologic examination, in 42 macrometastases were diagnosed, and in 2 micrometastases to the axillary lymph nodes. For this reason, in 32 patients axillary dissection was performed, while in the above-mentioned 10 patients, additionally mastectomy was performed. Only in 8 patients who had lymphadenectomy performed were metastases to further axillary lymph nodes found, whereas in 24 women no metastases were observed. In the group of patients who had undergone radical mastectomy (10 patients), in 3 women metastases to further axillary lymph nodes were diagnosed. In 7 patients, due to the failure of sentinel lymph node mapping, axillary dissection (AD) was performed. Only in 1 patient in this group were metastases to lymph nodes found, whereas in 6 patients no metastases were observed. In none of the patients who had undergone surgery were no cancer cells found within the surgical margins. After completion of the surgical treatment, the patients were subjected to adjuvant therapy. The most frequent-

Table I. Characteristics of patients

\begin{tabular}{|c|c|c|}
\hline Characteristics & Number & Percentage \\
\hline \multicolumn{3}{|l|}{ Age [years]: } \\
\hline$\leq 45$ years & 17 & 8.0 \\
\hline $46-55$ & 43 & 20.2 \\
\hline $56-65$ & 75 & 35.2 \\
\hline$>65$ & 78 & 36.6 \\
\hline \multicolumn{3}{|l|}{ Stage: } \\
\hline T1a & 5 & 2.5 \\
\hline T1b & 39 & 18 \\
\hline T1c & 104 & 49 \\
\hline $\mathrm{T} 2$ & 64 & 30 \\
\hline $\mathrm{T3}$ & 1 & 0.5 \\
\hline \multicolumn{3}{|l|}{ Histopathologic type: } \\
\hline $\begin{array}{l}\text { Ductal carcinoma, } \\
\text { no special type }\end{array}$ & 186 & 87.5 \\
\hline Lobular carcinoma & 16 & 7.5 \\
\hline Other & 11 & 2 \\
\hline \multicolumn{3}{|l|}{ Estrogen receptor: } \\
\hline Positive & 190 & 89 \\
\hline Negative & 23 & 11 \\
\hline \multicolumn{3}{|l|}{ Progesterone receptor: } \\
\hline Positive & 172 & 80 \\
\hline Negative & 41 & 10 \\
\hline \multicolumn{3}{|l|}{ HER2 receptor: } \\
\hline Positive & 21 & 10 \\
\hline Negative & 192 & 90 \\
\hline \multicolumn{3}{|l|}{ Grade (G): } \\
\hline I & 81 & 38 \\
\hline ॥ & 99 & 46 \\
\hline III & 16 & 7 \\
\hline Unknown & 17 & 7 \\
\hline
\end{tabular}


Table II. Adjuvant therapy

\begin{tabular}{|lcc|}
\hline Adjuvant therapy & Number & Percentage \\
\hline Chemotherapy & 2 & 0.9 \\
\hline Radiotherapy & 3 & 1.4 \\
\hline Hormone therapy & 5 & 2.3 \\
\hline $\begin{array}{l}\text { Chemotherapy } \\
\text { and radiotherapy }\end{array}$ & 14 & 6.6 \\
\hline $\begin{array}{l}\text { Chemotherapy } \\
\text { and hormone therapy }\end{array}$ & 5 & 2.4 \\
\hline $\begin{array}{l}\text { Chemotherapy } \\
\text { and immunotherapy }\end{array}$ & 1 & 0.5 \\
\hline $\begin{array}{l}\text { Radiotherapy } \\
\text { and hormone therapy }\end{array}$ & 113 & 53.1 \\
\hline $\begin{array}{l}\text { Chemotherapy, } \\
\text { radiotherapy, and hormone } \\
\text { therapy }\end{array}$ & 51 & 23.9 \\
\hline $\begin{array}{l}\text { Chemotherapy, } \\
\text { radiotherapy, } \\
\text { and immunotherapy }\end{array}$ & 7 & \\
\hline $\begin{array}{l}\text { Chemotherapy, } \\
\text { radiotherapy, } \\
\text { hormone therapy, } \\
\text { and immunotherapy }\end{array}$ & & \\
\hline
\end{tabular}

ly applied chemotherapy regimens were: Adriamycin and cyclophosphamide (AC - 55 patients); in 36 patients, apart from the $A C$ regimen, taxanes were additionally used; and in 1 patient the CMF regimen (cyclophosphamide, methotrexate, and 5-fluorouracil) was applied. Immunotherapy, in case of indications, was started after the completion of chemotherapy and continued during radiotherapy. Trastuzumab was administered to 20 patients (Table II). After treatment, the patients were subjected to check-up examinations which were performed and documented by the physicians from the Specialist Outpatient Departments at the Holycross Cancer Center.

\section{Statistical ananalysis}

Statistical analysis and graphic interpretation of the results was performed using the package MS Office 2010 with the license of the authors of this article, and the software Medical Bundle for Statistica 12, and SAS Enterprise Guide with the license from the HCC in Kielce. Basic statistics were calculated: arithmetic mean, standard deviation, median, and extreme values. The frequency of occurrence of individual categories of the variables analyzed was presented in absolute numbers and percentages. In the case of characteristics of the sentinel lymph nodes the median value and lower and upper quartiles were used. The probability of surviving without symptoms of the disease and the probability of overall survival were estimated using the Kaplan-Meier method.

\section{Results}

The mean follow-up of patients in our study was 61 months (min. 29, max. 89 months). During this time, recurrence of the disease was noted in 7 patients; 5 patients died (4 patients due to the spread of the disease, 1 due to a second carcinoma - gastric cancer) (Table III). The mean disease-free survival was $60.8 \pm 24.7$ months (minimum: 1 month, maximum: 89 months, median: 54 months). Based on the Kaplan-Meier estimator of the survival function it was found that the probability of 1-year disease-free survival was $99.5 \%, 24$ months - 98.6\%, 36 months - 97.2\%, 60 and 120 months $-96.2 \%$ (Figure 1). The mean overall survival was $61.6 \pm 23.8$ months (minimum: 29 months, maximum: 89 months, median: 54 months). Based on the Kaplan-Meier estimator of the survival function it was confirmed that the probability of overall survival for 60 and 120 months was $96.4 \%$ (Figure 2). Based on individual medical observations, no complications were observed in patients who had undergone sentinel lymph node biopsy, nor such complications as edema of the upper extremity at the surgical site, mobility and sensation disorders which, to a considerable extent, affected the quality of life.

\section{Discussion}

In the last decade, there has been major debate on the value and extent of axillary surgery. The data from the NSABP B-32 study proved that overall survival and disease-free survival were the same in patients subjected to sentinel lymph node biopsy and those who had undergone axillary dissection [13]. Also, the number of recurrences in the axillary region occurred in a low percentage of patients treated with the use of this procedure $[13,14]$. In the analyzed group, a recurrence in the axilla was observed in 1 patient. Even when excluding patients who had undergone axillary dissection or mastectomy (42 women), the percentage of recurrences in the axilla was $0.5 \%$. In the study by Veronesi, after 10 years of follow-up a recurrence in the axillary region occurred in $0.8 \%$ of patients [15]. At present, this is a well-elaborated and commonly applied procedure, especially in patients with early breast cancer with clinically unchanged lymph nodes. After microscopic examination of sentinel lymph nodes in 162 (75\%) patients no metastases were diagnosed, in 2 micrometastases were diagnosed, while in $42(21 \%)$ patients macrometastases were diagnosed. Axillary dissection was performed in case of metastases in sentinel nodes. However, in only 11 out of 42 patients qualified for further surgical treatment, metastases were found in the axillary region. In only 2 patients, in whom AD was 


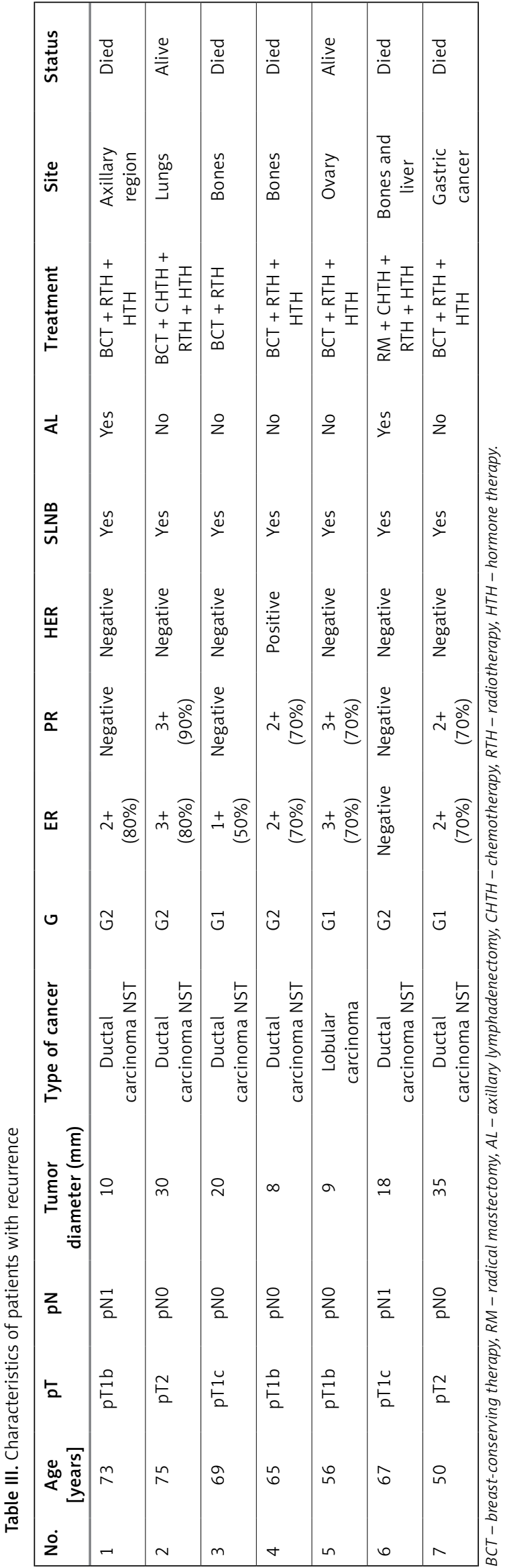

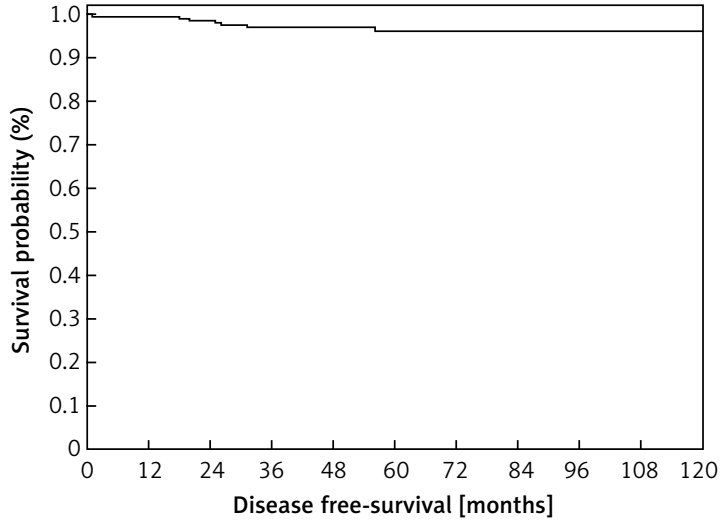

Figure 1. Probability of disease-free survival

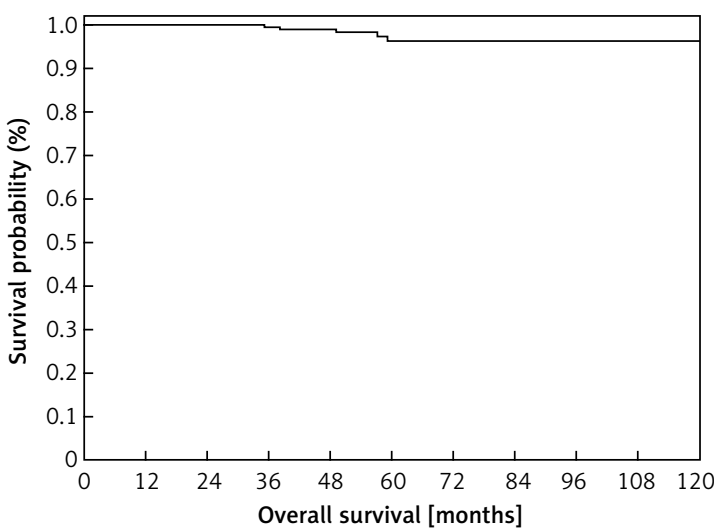

Figure 2. Probability of overall survival

performed after the SLNB, a change from pN1 to pN2 was observed. At present, it is commonly accepted that in case of metastasis to the sentinel lymph node, $A D$ is not performed [12]. Recent international and Polish guidelines also indicate the lack of necessity for performing axillary dissection in case of macrometastases to 1-2 sentinel lymph nodes according to the Z0011 trial [13, 14, 16-22]. In the analyzed group of patients, in 7 women the sentinel lymph node was not identified, which constitutes a percentage similar to the data from the literature [23, 24]. All patients underwent axillary dissection but only in 1 patient were macrometastases diagnosed (in 11 out of 17 lymph nodes removed). Nomograms may be helpful in the identification of patients in whom axillary dissection is not necessary, which, based on logistic regression, determine the probability of occurrence of metastases to the sentinel lymph node or to non-sentinel lymph nodes for each patient [25-29].

The treatment outcome of breast cancer patients subjected to multidisciplinary therapy with the use of sentinel lymph node biopsy in the Holycross Cancer Center is satisfactory. Based on our experience, it was confirmed that the absence of metastases to the sentinel lymph nodes does not constitute an indication for axillary dissection. However, further studies are mandatory concerning the identification of patients in whom me- 
tastases to the axillary sentinel lymph nodes are diagnosed, and who do not require axillary dissection, considering the fact that in many patients in whom the surgical procedure in the axilla was radicalized, metastases to additional non-sentinel lymph nodes were not found.

\section{Conflict of interest}

The authors declare no conflict of interest.

\section{References}

1. Urban JA, Baker HW. Radical mastectomy in continuity with en bloc resection of the internal mammary lymphnode chain; a new procedure for primary operable cancer of the breast. Cancer 1952; 5: 992-1008.

2. Halsted WS. I. The results of operations for the cure of cancer of the breast performed at the Johns Hopkins Hospital from June, 1889, to January, 1894. Ann Surg 1894; 20: 497-555.

3. Guliano AE, Kirgan DM, Guenther JM, Morton DL. Lymphatic mapping and sentinel lymphadenectomy for breast cancer. Ann Surg 1994; 220: 391-8.

4. Guliano AE, Hunt KK, Ballman KV, et al. Axillary dissection vs no axillary dissection in women with invasive breast cancer and sentinel node metastasis: a randomized clinical trial. JAMA 2011; 305: 569-75.

5. Galimberti V, Cole BF, Zurrida S, et al. (International Breast Cancer Study Group Trial 23-01 investigators). Axillary dissection versus no axillary dissection in patients with sentinel-node micrometastases (IBCSG 2301): a phase 3 randomised controlled trial. Lancet Oncol 2013; 14: 297-305.

6. Gentilini O, Veronesi U. Abandoning sentinel lymph node biopsy in early breast cancer? A new trial in progress at the European Institute of Oncology of Milan (SOUND: Sentinel node vs Observation after axillary UltraSouND). Breast 2012; 21: 678-81.

7. Black DM, Hunt KK, Mittendorf EA. Long term outcomes reporting the safety of breast conserving therapy compared to mastectomy: 20-year results of EORTC 10801. Gland Surg 2013; 2: 120-3.

8. Zumsteg ZS, Morrow M, Arnold B, et al. Breast conserving therapy achieves locoregional outcomes comparable to mastectomy in women with T1-2NO triple negative breast cancer. Ann Surg Oncol 2013; 20: 3469-76.

9. Guliano AE, Dale PS, Turner RR, et al. Improved axillary staging of breast cancer with sentinel lymphadenectomy. Ann Surg 1995; 222: 394-9.

10. Veronesi U, Paganelli G, Viale G, et al. A randomized comparison of sentinel-node biopsy with routine axillary dissection in breast cancer. N Eng J Med 2003; 349: 546-53.

11. Krag DN, Anderson SJ, Julian TB, et al. Technical outcomes of sentinel-lymph-node resection and conventional axillary-lymph-node dissection in patients with clinically node-negative breast cancer: results from the NSABP B-32 randomised phase 3 trial. Lancet Oncol 2007; 8: 881-8.

12. Mansel RE, Fallowfield L, Kissin M, et al. Randomized multicenter trial of sentinel node biopsy versus standard axillary treatment in operable breast cancer: the Almanac Trial. J Natl Cancer Inst 2006; 98: 599-609.

13. Krag DN, Anderson SJ, Julian TB, et al. Sentinellymph-node resection compared with conventional ax- illary-lymph-node dissection in clinically node-negative patients with breast cancer: overall survival findings from the NSABP B-32 randomised phase 3 trial. Lancet Oncol 2010; 11: 927-33.

14. Van der Ploeg IM, Nieweg OE, Van Rijk MC, Valdes Olmos RA, Kroon BB. Axillary recurrence after tumournegative sentinel node biopsy in breast cancer patients: a systemic review and meta-analysis of the literature. Eur J Surg Oncol 2008; 34: 1277-84.

15. Veronesi U, Viale G, Paganelli G, et al. Sentinel lymph node biopsy in breast cancer: ten year results in randomised controlled study. Ann Surg 2010; 251: 595-600.

16. Krzakowski M. Zalecenia postępowania diagnostycznoterapeutycznego w nowotworach złośliwych $u$ dorostych. PUO 2013; 212-63.

17. Guliano AE, Hunt KK, Ballman KV, et al. Axillary dissection vs no axillary dissection in women with invasive breast cancer and sentinel node metastasis. JAMA 2011; 305: 569-75.

18. Ho A, Morrow $M$. The evolution of the locoregional therapy of breast cncer. Oncologist 2011; 16: 1367-79.

19. Reimer T, Hartmann S, Stachs A, Gerber B. Local treatment of the axilla in early breast cancer: concepts from National Surgical Adjuvant Breast an Bowel Project B-04 to the Planned Intergroup Sentinel Mamma Trial. Breast Care 2014; 9: 87-95.

20. Wazir U, Manson A, Mokbel K. Towards optimal management of the axilla in the context of a positive sentinel node biopsy in early breast cancer. World J Clin Oncol 2014; 5: 792-4.

21. Gatzmeier W, Mann GB. Which sentinel lymph-node (SLN) positive breast cancer patients needs an axillary lymph-node dissection (ALND)-ACOSOG Z 0011 results and beyond. Breast 2013; 22: 211-6.

22. Hieken TJ, Boughey JC. Axillary dissection versus no axillary dissection in patients with sentinel-node micrometastases: commentary to the IBCSG 23-01 Trial Gland Surg 2013; 2: 128-32.

23. Zanghi G, Di Stefano G, Caponnetto A, et al. Breast Cancer and sentinel lymph node micrometastases: indications for lymphadenectomy and literature review. G Chir 2014; 35: 260-5.

24. Posther KE, McCall LM, Blumencranz PW, et al. Sentinel node skills verification and surgeon performance: Data from multicenter clinical trial for early-stage breast cancer. Ann Surg 2005; 242: 593-9.

25. Van Zee KJ, Manasseh DM, Bevilacqua JL, et al. A nomogram predicting the likelihood of additional nodal metastases in breast cancer patients with positive sentinel node biopsy Ann Surg Oncol 2003; 10: 1140-51.

26. Degnim AC, Reynolds C, Pantavaidya G, et al. Non sentinel node metastasis in breast cancer patients: assessment of an existing and a new predictive nomogram. Am J Surg 2005; 190: 543-50.

27. Pal A, Provenano E, Duffy SW, Pinder SE, Purushotham AD. A model of predicting non-sentinel metastaic disease when the sentinel lymph node is positive. Br J Surg 2008; 95: 302-9.

28. Coutant C, Olivier C, Lambaudie E, et al. Comparison of models to predict nonsentinel lymph node status in breast cancer patients with metastatic sentinel lymph nodes: a prospective multi-center study. J Clin Oncol 2009; 27: 2800-8.

29. Cserni G, Boross G, Maraz R, et al. Multicentre validation of different predictive tools of non-sentinel lymph node involvement in breast cancer. Surg Oncol 2012; 21: 59-65. 